\title{
Acuut visusverlies
}

\section{WAT IS HET PROBLEEM?}

Acuut visusverlies komt weinig voor in de huisartsenpraktijk. Onder acuut visusverlies verstaan we een visusdaling binnen enkele minuten tot uren tot een visus lager dan o,1 (10\%). Het visusverlies verloopt meestal zonder voortekenen. Om onherstelbaar functieverlies te voorkomen, moet de patiënt bij volledig aanhoudend visusverlies binnen enkele uren bij de oogarts zijn. Bij tijdelijk visusverlies is het lastiger te bepalen in hoeverre de verwijzing spoedeisend is.

\section{WAT MOET IK WETEN?}

Acuut visusverlies treft vooral ouderen vanaf 65 jaar. De oorzaak van een pijnloze, acute visusdaling is meestal een loslating van het glasvocht of retina, een stoornis in de bloedvoorziening van het oog of afwijkingen van de nervus opticus.

Bij kortdurende klachten van visusverlies die enkele seconden tot maximaal 30 minuten aanhouden, valt te denken aan retinale migraine, amaurosis fugax of glasvochtloslating. Bij retinale migraine is er sprake van vaatspasmes van de retinale vaten die zorgen voor tijdelijk visusverlies. Amaurosis fugax is een vluchtige totale blindheid aan één oog die plotseling ontstaat door een verstoorde bloedtoevoer van het netvlies en na enkele seconden tot minuten weer geheel verdwijnt. Glasvochtloslating komt regelmatig voor bij patiënten vanaf 50 jaar door een verminderde elasticiteit van het glasvocht. Dit zorgt voor hinderlijke, maar ongevaarlijke, bewegende vlekjes of draadjes (mouches voulantes) die na enkele weken tot maanden vanzelf verdwijnen.

Bij acuut visusverlies dat langer dan 30 minuten aanhoudt, zijn de mogelijke oorzaken: afsluiting van de arterie of vene centralis retinae, glasvochtbloeding of netvliesloslating. Een afsluiting van de arterie leidt tot snel optredend visusverlies, terwijl dit bij een afsluiting van de vene geleidelijk optreedt. Bij een glasvochtbloeding ontstaat er acuut visusverlies, waarbij de patiënt helemaal niets meer ziet aan het aangedane oog of tussen zwarte vlekjes doorkijkt. Bij een netvliesloslating (ablatio retinae) ontstaat acuut verlies van gezichtsscherpte en gezichtsveld, vaak voorafgegaan door lichtflitsen. In zeldzame gevallen is een neuritis van de nervus opticus of een centrale aandoening de oorzaak. Juist bij begeleidende symptomen of andere oogklachten, zoals dubbelzien, wordt een centrale oorzaak waarschijnlijker.

\section{WAT MOET IK DOEN?}

Vraag goed uit of de patiënt niets meer ziet of minder ziet. Vraag of het visusverlies één of beide ogen betreft. Als het om beide ogen gaat, is een oogaandoening onwaarschijnlijk. Vraag hoe (snel) het visusverlies is ontstaan en of het er nog steeds is. Een arteriële afsluiting, glasvochtbloeding en netvliesloslating ontstaan binnen enkele minuten. Het beloop van een netvliesloslating en neuritis opticus neemt in en- kele uren tot dagen progressief toe. Vraag of er voortekenen of begeleidende symptomen zijn, zoals hoofdpijn of lichtflitsen. Een 'gordijn dat dichtgaat of omlaag valt' kan duiden op een netvliesloslating of amaurosis fugax, terwijl het zien van zwarte vlekken bij een glasvochtbloeding past. Een scotoom en lichte pijn achter het oog bij oogbewegingen past weer eerder bij een neuritis van de nervus opticus.

Controleer bloeddruk en pols, en ausculteer het hart om atriumfibrilleren als mogelijke oorzaak van trombose van de a.retinalis door embolieën op te sporen (amaurosis fugax). Controleer de directe pupilreactie; deze is afwezig of gestoord bij arteriële en veneuze vaatafsluitingen, maar intact bij een netvliesloslating of glasvochtbloeding. Controleer de fundusreflex. Bij een glasvochtbloeding zijn er zwarte vlekken. Bij een netvliesloslating wordt de fundusreflex rood met grijs en bij een veneuze afsluiting is er een vlekkerig rood beeld te zien. Voer de gezichtsveldbepaling volgens Donders uit om een hemianopsie uit te sluiten en spoor mogelijke scotomen op met het amslerkaartje.

Verricht in alle gevallen van acuut visusverlies uitgebreid onderzoek met een spleetlamp en indirecte fundoscopie. Hebt $\mathrm{u}$ deze niet tot uw beschikking of bent $\mathrm{u}$ onvoldoende getraind in het gebruik, verwijs dan met gepaste spoed naar een oogarts. Arteriële afsluitingen moeten binnen zes tot acht uur worden gediagnostiseerd voor een zinvolle behandeling. Netvliesloslatingen, glasvochtbloedingen en veneuze trombose moeten binnen één dag worden behandeld.

\section{WAT MOET IK UITLEGGEN?}

Leg op basis van uw bevindingen uit wat de mogelijke oorzaak voor het acute visusverlies zou kunnen zijn en licht zo nodig toe dat $u$ de patiënt direct doorstuurt naar een oogarts. Deze heeft namelijk betere middelen tot zijn beschikking om de juiste diagnose te stellen en de aandoening adequat te behandelen. Leg bij glasvochtloslating uit dat de klachten naar verloop van tijd vanzelf verdwijnen. Geef bij retinale migraine dezelfde adviezen als bij conventionele migraine.

\section{LITERATUUR}

1 De Jongh TOH, Grundmeijer HGLM, De Vries H, redactie. Diagnostiek van alledaagse klachten. Bouwstenen voor rationeel probleemoplossen. Derde druk. Houten: Bohn Stafleu van Loghum, 2011.

2 Keeman JD, Schadé E, redactie. Spoedeisende hulp in de huisartsenpraktijk. Houten: Bohn, Stafleu van Loghum, 2008.

3 www.oogartsen.nl/oogartsen/overige_oogziekten/tijdelijk_verlies_zicht. 4 Stilma JS, Voorn ThR, redactie. Oogheelkunde. Tweede, herziene druk.

Universiteit Maastricht, School for Public Health and Primary Care (CAPHRI), vakgroep Huisartsgeneeskunde, Postbus 616, 6200 MD Maastricht: L.J.L. Ploum, basisarts; dr. J.W. Cals, huisarts en onderzoeker • Correspondentie:j.cals@maastrichtuniversity.nl 